\begin{abstract}
!

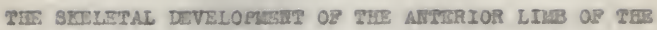
OUINE-PIQ, CAVIA COBAYA CUV., KROU TWS 25-DAY IITBRYO TO TIE 16I-DAY POSF NATAL GUINEA-PIE
\end{abstract}

\title{
$\mathrm{bg}$
}

OLEA BARBARA SAFFT

B. S.. Kansas State College

of Acricul ture and Applied Solence, 1928

A mesis

subutted in partial fulrillabent of the

requirements for the degree

MASTER OF SCIEUCB

KAWBAS STATE COLISGE

OF AGRICULTURS AND APPLIBD SCIENCE:

1935

KANSAS STATE COLLEG̈- LIBRARIES 


\section{TABLB of CONTENTS}

IMTR OUUCTIOI

page

Purpose ....................................

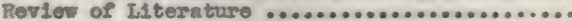

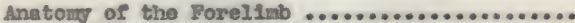

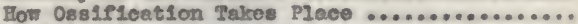

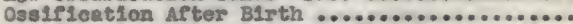

Variation in Rate of Ossifleation of Bones

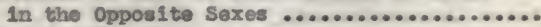

Petroerespente

IIscussIon $\ldots \ldots \ldots \ldots \ldots \ldots \ldots \ldots \ldots \ldots \ldots \ldots$

SUMURTY

ACTNOTLEDGLETS

20

LITERATUPE CITED

21

BXPLANATIOI OP PLATES

...........................

23

\section{INTRODLCYPION}

Whoh worls has been done on the develoyment of the human skeleton. Some work has been done on birds and the albino rat, but very little research has been alrected toward the bone development of the guinea-p15. Ihis study represents a part of a serles of studies on the enbryology of the guinea-p18. 
Purpose

The purpose of this research hae been to determine the perlod in fetal I1fe whon ossification elrst begins, how it progresses, when it is completed, and how it varies in rate of development In opposite sexes, as well as to doterwine the retrogressive ohanges which oecur in the formation of the root.

\section{Review of Iltereture}

No 11 torature was found on the normal bone developmont of the guinee-pig, but Speriks and Dawson (1923) in theis study of the bone develoyment of the alblno rat noted that most of the centers of ossifleation are lald down in a relatively short time elther in utero os in the perlod betwoon blxth and weaning.

Strong (1925) in woriding vith the rat found that the clavicle 1s the firat bone to oasify and that most of $1 t$ is ossifled at birth. Ho found, that in the ossisleation of tho phalenges, that as in mucuans, the terminal phalanges are the flrat to osalfy and the second phalanges the lest. He also found that "arthough ossiflestion takes place wroh more rapldig in the rat than in man, it never ceaaes while the arimar 1a elive". 
Pryor (1925) observed that in humans there are instances of normal oariy ossification in both soxec, and that there are normel cases in which ossipioation is deiajod. In elther case he believes that this is dive to heredity. Apparentiy the order of ossification of the bones of the earpos 28 the serse in both sexes. Pryor (2983) obwerved that tho bones of a first: ohild osaify, as a rule, sooner than those of aubaequent ohtldren. In the fomale there is somplete union of the epiphyses of netacarpal bones and the phalmges at alxteen jears. In meles in most ereses this union is not sompleted unt11 between 10 and 20 jegres of age.

Dewson (1927) deacribes the clearing and staining of sheletons with alizarin red. He developed this teohnigue with rat material.

\section{MATSRIALS AND IBBTHODS}

The antrais used in this seseareh wore socured through

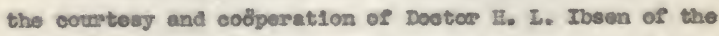
Animal Husbemory Dejartwent, Jansas State Colloge. Woat of the ansranla were from the colory descrtbed of llasman and

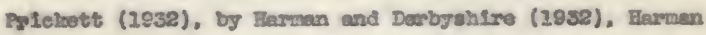
and Dobrovolng (2933), and winters (1933). Besides this meterial, specimens vere secured from Doctor Ibsen. These 
vere the animals used in his paper on the prenatal frowth In Guinoe-pigs (Ibsen, 2928 ).

4 total of 70 enimals was examined. of these, 21 were nales, 25 wore fomales, and the sex of the remalning 24 was not identirled. Mis Inciaded animals between the ages of 25 day embryos, copulation age, and 161 days post natal cevelopmont. The age of the embryos vas determined by the method deseribed by Farmen and Prickett (1932) and wintera (1935). The aex in all specimene vas deterained by external gonital1a.

Gross andomsol alssectlons were stualed together with transpexent speciwens which were prepared by the process described by Dawson (1926). Ey vie of this proeess the $\mathrm{Nlesh}$ and cartliage were sendered transparent and the bones were stalned with alizarln rod. When these cleared apecinons were placed in a Petri al oh over a photographie printing box, the 1 ight penetreted the t1asue so that the very alightest ossifloation covid bo detected. Tho younger aniwals wore examined with a binocular microseope. The bones of aninais between the agea of 40 day embryos, copulation ago, and 75 dags post natal development taken at Interval: of f1vo Aaga were dissected from the other tissues and measured with calipors to determine the anount of oasiflest1on at the various stages. 
Some of the materlal was Plsed in 7 per cest formelin. some in Borin's Pluld, and wo in 85 per cent aleohol. Iluminat1ng gas was found the most satisfactory for k1111ng the animals of post natal ceveloperent and the pregnant mothere.

The fotal membranes vere renoved from the exbryos. Then the smaller onbryos vere $51 \times 0 d$, cleared and stalnod 10 toto. In the Iarger ambaryos and in the post natel animals one froat eppendingo vas removed from the bocty. The skin, wost of the Plesh, and the fat were cut away. This was done so that the clearing process would be more simple. The other appendage was anved for referenoe.

\section{OBSBRVATIONS}

Since no record of the anatomy of the skeleton of the gulnea-pig was found, $1 t$ was necessary to make a study of the anatoury of the bones of the rront $2 \mathrm{eg}$.

\section{Anatom of the Forelimb}

The forelinb of the guinea-pig consists of the acapula. clav1cle, humerus, radius, ylna, elght carpals, four algits, each of which consists of a metrearpal and three phaianges; and a rudiment of a fifth digit which is composed of two bones (F1g. 4). It 18 asgrumed, in this case, that the two 
bones are a sudimentary motecarpel and one phalanx (F1g. 4. Fin and PII). A maber of sesamold bones are found on the volas sunface of the foot (FIg. 2, $s$ end $s^{2}$ ). We flnd that In each of the four difgits there are two sesanold bones whlen 110 parellel to one another at the polnt of the articvlation of the motaerryel and the rirat phalanx (FIg. 2, S). These two banea are parallel to the phalauges. In sddition to these there 18 another sesamola bone on each of the sour diflts, which extonds erosawise where the aistal phelanx exticulates with the second phalanx (Fig. $2, s^{2}$ ). 4 smenl sesamole bone which couresponds to the pisiforn 11es ventral to the proximel ond of the I1Fth metacarpel. In the adult these is a sesersold bone in the warking pad of tho foot just ventrel to the fourth and PIfth motrearpala.

The carpals are axranged in two rows, a proximal row of three bones and a datal row of sive. In the proxlmal row from the redial (thumb or rhdiale side) to the lateral sice, the Pollowing bonos are found raclale, lunare, and ulnare; and In the alstal row following the sawe order the trapezlum, trepezold, contralo, capltato, and hasate are present (FIg. 4). The claviele is verry small. It is a slender curved rod of bone imbedded in the unecle of the shoulder. The seapula is a flat bone with a spine on the dorsal surieces The apine unites with the body of the scapula from the prox- 
Imal edse of the boct for a elstance which is approximately half the length of the weapula.

\section{How Ossifleation Falros Place}

The Plrat bone to shou ossizloation 28 the elavielo. A silght ossirleation about tho aszo of a pln polnt wa observed in the enimgro of 25 degs copusation ago. In the next three days there was vory $11 \mathrm{t} 10$ change in ossification. Ho other centers of ossification epposred, and trere it only a slight Inorease in the osalfiestion of the entire vone. In oribryos fron 23 to 31 days copulation age, canters of oaslf1ention sppear in the seapula, radius, vine and bumerus. Ossiflcation in the redive, wine and humerus appears a a center locatod at the midile of each of the alapityses. In each case the osalfieation eenter increases rapldig in density and oxtends toward both onds. In embryos of 31 days eopriation age oseleleation has progressed to the atage where about half of the eartilaginove fundament of the shapts is eorpleted in the long bones. The scapula has a large ossif1eation center which includes nost of the body and the aplne. The apine extonds well above the body of the soapula. but the seromion and crracold processes cannot bo distingulsiced at this eariy stage. 
In the 35 day embryo ossifieation centers were observed In the second, third, and fourth metacarpela, ss well es in the distal phalanges of the seeond, third, fourth and fifth diglts. The corneold provess has stapted to forme

In moryos of 40 days copulation age a center of oss2Plection has appeared in the shart of the PIfth motsearpal (FIg. I, $\mathrm{u}^{3}$ ), and one in the first phalanx of each of the seoond, thire, fourth and PIfth Algits (FIG. 2, P). The aress undergoing ossifisation in the radius, ulne, asd humorrus have elongatod and taike a hoavier stain at each ond. The seapula taices a doog strin axcound the region of the glenold eavity and in the roglon fast sbove it in the acrowion process. Tala indieates that ossification is taking place. The elaviele has at progressed beyond the stage observed In the 35 day embryo. The pollex is foldod over the volax axcsece of the soot, but the diletal end is still free and projeets out beyond the enre face of the poot.

In the 45 day ombryo, centers of ossirication have appeared In the seoond phalanx of the senend, third, fourth and IICh diglta. The areas ossipod in the motacarpars have elongated eonsilearably.

In tho 51 day embryo two smell conters about the size of a pin point are iying sldo by side in the distal epiphysis of the radius. The distal and proximal opiphysia of the 
ulne ench have two centers of ossifleation. The upper epiphysis of the humerus has in the lateral side two small centers of ossification which Ile alde by alde, and a lerger onslfication center in the lower opiphasis. A center of ossifieation appears in the radiale, and one in the hasate. Mhere is a center of osalfioation on the distal margin of the acromion process. This large center of ossificetion is uniting with the body.

In the 55 day embryo there is a secondary center of ossification presont in the radiale (P1G. S, RA), and the vinere (Fig. 3, E), and a primay center of ossificetion in the Iunere (PIg. S, L). In the Plrst phalanx in eech of the socond, thixd, fourth, and firth aigita a certer of ossif1cation Ia found in the peoximal epiphysis. A center of ossification is found in the eapitate (FIG. 3, C), and one In the pasoximal epiphysis of the radius (FLG. 3, EP).

In the 60 ing enbryo the centrale, the trapezold, the trapezium and the first watacorpal each has an ossiflcation center. The two mald centers of ossiescation which were observed in the proximal epipizysis of the humeras in the 51 day enioryo heve united and form the greater tuberosity of the opiphysis in the proxinal extremity of the humerus (B1g. 3, GE). Another center has appeared which forms the lesser tuberosity. There was observod a conter of ossiflca- 
tion os plate distal to the radiule. Of the two sesemold bonos whloh 110 on the volar arefeee of the foot in the adult at the artieuiation of the netaearpal ond the firat phalarx ( 1 18. 2, S) the one on the laternl slde of each Afglt has a cantsr of osilfieation thieh Includes about half of the careliaginous fudament. Both ossirleation centers in tho vinare have enlarged but the renain apart.

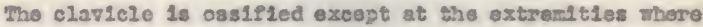
growth is occurring. Mhore is a canter of ossifleatson in the phalans of the gollex or tho glrat digtt.

In the 65 day axdoryo there was observed a center of ossterteation In each of the second or rastil al sersamold bones vilch 110 on the Fclar surface of the watacarpal-phalanx artevist1on, and center of ossiflention in ench of tho sesanold bons on the artioulation of the second and thire pholanges (FLs, 2, $3^{2}$ ). mero is an ossipleation center in the cartilage on the maxein of the acromiton procoss.

\section{Oasifleation After Birth}

At birth the epiplagsis of the proximal extrenty of the humeras is st111 drided. The two canters of ossiflestion 2n the ulnare are soparated by a congaratively wide angin. All of the eplpiryses of the liwalanges are free from tho 3hafts. The cleviele is about $3.3 \mathrm{~mm}$. In length. Two 
centers of ossification in the distel extremity of the third phalans are loeated on erch alde, laterel and medial. Theae glve the elav an appearance of the toes on a eloven foot of some of the higher vertebrates (PIg. 4, FI).

In the gulnee-pig of 15 deyt poet natal developnent. anothor center of ossifleation was obeerved in the eartilage bordering the seromion process. The centers whles had been observed previously had unlted with the body of the process. The humerus has a eonter of ossteleation in the medial eptcondy 2e. The head of the radivs which is quite flat is free from the ehert.

In the guinea-pig of 27 days post natal 1190 , eenter of ossirlcation wes observed in the cartilaginous sundament bordering the ecrovion process. In the guines-p1g of 18 days post natel 11 fe an ossifieation centor wes observed in the seme position, and between this ossirleation center and the body of the process were found three very small centera in a row parallel to the large center and the body. In this animal, for the Plrst t1mo, we observed an oselfleation center in a cartilage veatral to the proximal end of the PIfth motacerpel. This apparently is the plelform. This bone wes found in enimels of 26 daye, 75 days, 95 deys of post neter $11 f e$ and in the selult, but in all oases it remeined verg amall (about $1 \mathrm{~mm}$. In length). 
In the guinea-pig of 75 dags post natal 11Pa, wo observed a conter of ossifleation in the cartilage bordoring the acromion process. Tho polnt on tho process 1 a atill very blunt. There was observed a centes of ossifleation in each the corsal and ventral aldes of the cartilaginous fundsnont on the vortobral margin of the scapula. The two conters In the wina have unsted.

In the GuInea-pig 161 days after birth, we observed a center of ossification in the cartilaginous fundarnent on the lateral sles of the valking pad formed by the folding over of the first digit. This is apparentig a seanold bone formod in tho tendon which is found fastening the walleing pad to the Iateral side of the foot. All of the eplphyoes were Ireo from the diaphyses. It was noted that the centers of oasifleation in the cartilaginoua fundament on the vertobral edge of the scapula extended almost the entire as stanee sron the ventral to doral aldes. The dorar projection of the acromion process was guste short comparpd with the projeetion found in the actult suinosoplg.

Ossifleation was not complete in any of the bones exeept the claviele.

In the atuits which were examined in each case we found that the eplphyres had not made complete union with the alaphyses. The wost apparent example of incomplete oas1510a- 
tion in every case could be observed in the ossiplestion and union with the boty of the vertebrel margin of the acapula. In the oldest aninal examined which had reached the age of two joars, 12 monthe and 10 devs, there vas a alstinet IIne between the vertebrel wargin and the boty of the seapria.

\section{Varlation in Rate of Ossifleation of Bones In the Opposite Sexes}

Bofiming with exibryos of 51 day eopulation age and taleing two of each age at fIve day Intervals until birth (SB cays) end of animals after birth at about f1ve lay Intervels unt1l 45 daye post natal 11f0, we observed the developmont with speclal referenee to sexusl alfferenoes in rate of ossifleation. In aase of the amaller embryos both males and fomales of the eame age were fron the samo iltter thus providing the same nutriment and Erowth condle1ons. In moet of the older animels the maies and feratea of the aane age ware from different 12tters.

In no case did wo observe and signifient alfferrences In the rate of development of obsirication In the opposite sexes. The centers of osalfication were noted to appear in both malos and fonales at the seme ages, and no difforenee in the degree of osalfication was noted. 
. In Beneral there was noted a gradunl inerease In the length and width of the bones of the animals whleh were ercenalned.

There were exceptions in easos of the aninals of 26 days and 35 days of post natal 11fe. The male of 26 dayse post natal 11fe vas lerger than the female of the sane age. and osaffication of the bones in the mele was in acvanee of those in the fomale. In the case of the animale of 35 days of post natel 1150 the reverse condition was true. In this oase the fomnie was larger and ossifleation of the bones was in advence of that in the male. Since these animals though of the same age were from different 11tters, It appears thet these variations are probably due to individual afferences.

\section{Ratrogressive Changes}

FIve algits in the appendages ere eharacteristio of mammals. In the 25 day ombryo of the guinen-p1g four digits are present as elearly outlined projections and the fifth Alg1t appears on the ventral eurface of the foot in the thenor eminence as a bunp about the sise of a pin head. In the adult only four diglts are recognised externally. The renains of the pleth are found on the volax surface of the Poot Imbedded in the posterlor walking pad. Fhen it is 
dissected from the rest of the tissue it 11 ee back in the postition wrich corresponds to the therib in the hand. From the poestion which it occuples it is assuned that this rudimentary diglt is the poliex or the flrst diglt. It axtleulates whth the radiale. It 1 eomposed of two bones, a rudimentery metacarpar and one phalanx. The motacarpal has been modrfled into amall Plat ovold bone. The phal6sx 1. about as long as the second phalenx in the other digits, but $1 t$ is rlattened and the distal ond remalno eart1laginous. No asamold bones are preaent in this digit. The vinare, although considared a part of the proximal row of expale, occuples a position ventrel to the rest. The elaviele wilch is quite large in some of the nemang is very amail in the guirea-pig and apparently does not porform a doplnste function. In the edult it is only $10 \mathrm{~m}$. 1ong.

\section{prscussion}

The foregoing data show that as in the rat as deseribod by Sparizs and Deweon (1923) most of the primary centers of ossifleation are lald com early. The elaviele which is very amall is the flrst to ossify which fact Spariss and Dawson (1929) also found true in the rat. The Plxet phalnages are the firgt to show ossifleation centere 
and the seeond phalanges are the last. Thia differs from the rat sinee Sparics and Dawson (1928) report that the terminal phalanges were the f1rat to osalfy.

The perlod between 28 and SI days govtetion In the guinea-pig in witch mang of the prinary centers of osalfieation are lasd down colnoldes with the period of rapld devalopment of extermal form a doseribed by llasman and Dobrovolag (1935) in which they state. "After the 29th der the 2ength of the fetrus ard 1 ta component parte Increases replaly ... The length of the Potan at 51 dngs $1625.9 \mathrm{~mm}$. , a mariced inorase over the length at 29 deya".

The osalfication of the motsearpal and the phalanx in the flrst afgit taises place relatively 1 ate. Thls is probably dve to 1 ts sudimeatary nature.

WIth \& fev exceptions at least two anlmals of each age were examined. Of there one was a male and one a female. In naxy cases three or form apecimens of tho samo age were examined. In the case of the aninals of 75. 05 and 162 days of post notel $11 \mathrm{fo}$ oniy ono animal of each age was examinod. In the eubryos of 25, 26, 27, 23, 29 days of gestation no positive elaim of recognition of the sex of the exbryo could be made. Although several embryos of each of these ages were examined no comparison of sez differences were made. 
Soms of the apecimens which were discards from other experirients and had been IIxed In Bouln's fluta were used For alssection oxiy. Fnterisl which had been Fixed in Bouln's nusd could not be eleared unt1l all of the Plxat1ve had been washed out. This necessitated a prolonged process with a greater chance of nasceration of delloate tisarue. The presence of pleric ac1d in Bouln's pluld cauaes a cegreo of decalcirloation and destruction of ano of the amaller centers of ossiflcation whleh would lead to inacourate reaults. Por this reason all the jounger onbryos which were cleared and stalned wore sixed in 85 per cent sicohol for 24 to 48 hours and In 95 pers cent alcohol for 96 hours bofore clearlng in a 1 per cent solution of potasslum wotraxide.

\section{SUmARY}

1. The age and ordor of apperrence of the centars of ossiffeation fos exoh bone of the front leg of the gulnosp18 have been deternined.

2. The clavicle is the sirst bone to show ossiflestion which at 25 days gestation has a contere or ossirlcatlon about the size or a pln polnt. The elavielo is completely ossifled at birth excopt at the extremities whare growth oecurs. 
S. The noxt bones to show ossiflcation oanters aro the scapria, the humorras, the radius, and the vina. Theso appear In the parlod betwoen 28 nad 31 days gestation.

4. In the emibryo of 55 days copralation age centers of ossipleation appoar in the motacarpels, and in the terminal phalanges.

5. The coracold and acromlon processes ossify by moans of several osslfleation centers whlch are formod ancoesaively. They forn one at a time in the caxtinginous fundament on the margin of the ossisled area and spread unt12 they unite with the boty.

6. All the primary centers of ossirieation of all the boxas with the excoption of a fow sesamold bonen are prosent In the embryo of 60 days eopralation age.

7. Ossiplcation was not coruplete in my of the aximals exarinod.

B. Wo Alfferences in the rate of assification of bones of males anc fomalos wero noted in anthyos botween the sges of 32 degs gestation and birth (68 deys) or animals of one eng and 45 lays of post natra 11 .

8. Retrogression has ooeurred is the formation of the foot. There was a beginaing of five algits on the foot of the eribryo and only four diglts are present in the acult. 


\section{ACKNORLEDGUENS}

The author wishes to express her Indebtednoss to $\mathrm{Dr}$. Hary 2. Harman for the asa1stance, Buggestions and crit1alsms glven her while earrylng on this researeh, and to Dr. I. I. Ibsen of the Anival Elusbandry Department for his colperation in furnishing the animala for the experiments also, to llarjorle Prielcett Dobrovolng for her asalstence in the ICentipleation of the sex of the extbryos, and to other members of the Zoology Departmont for their assistance in methods of teoknigue. 


\section{LITERATUT: CIFED}

Dav1e. D. A, end Pareone, P. O.

The ege ordar of the appenrence and untan of the normal opiphyees as aoon by X-ravg. Anor. Jour. Bat. $62,58-71.2027$.

Dawson, A. B.

The extretion of fat rron apostmens prios to eleasing by the potan mothod. Selenee, 64:579-579. 1926.

A wote on the stalning of the skeleton of eleared gpelmons with alizarin sed 3. Staln Techologz. 2.125-184. 1927 .

Barman, Mary T. and Derbyehire, Russel cies

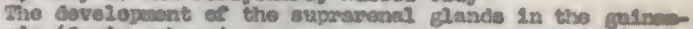

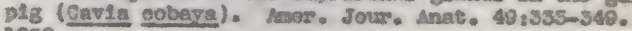
295e.

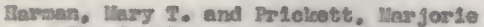

The development of the external form of the gulnespis (Cev1a sobaya) botweon the agoa of eleven caye and ewenty dore gostation. Amor. Jour. Arat. 49: \$51-575. 1932.

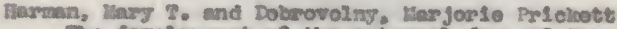

The fevelophent of the extermal form of the guineepis (Cavia cobaye) betwoen the agos of 21 days and

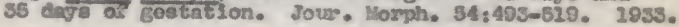

Ibeen, Iremaa $\mathbf{L}$.

Prenatal growth In Guinee-plga with apeelal referenee of environental faetors affeating weifot at birth.

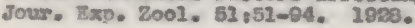

Pryor. J. II.

Difference in oasifleation of nale and fernile

alceleton. Amer. Jour. Anst. 64:490-506. 1008. 
Sparizs, Charles and Dawgon, A. B. The order and appearance of the centers of ossiflcation in the fore and hind 11 mbs of the albino rat. with speelal reference to the possible influence of the sex factor. Amer. Jour. Anat. 41:411-445. 1823.

Strong, R. Ix.

Order, time and rate of ossifleation of the albino rat (ius norvegicus albinus) sikeleton. Amer. Jour. Anat. 36:313-355. 1925.

Winters, Estelie Adele.

The development of the heart in the guinea-pig

(Cevia cobava). Unpublished thes1s, Innsas state college. 31 p. 2933. 
EXPLARATION OF PLATES 
FIg. 1. Right forelint of the 40 day embryo. X3. The stipled area ropreaents the extent of ossification. $D$, divtal or thlrd phalangos; $P_{3}$ first phalangos: $M$, the wetaearpale; $M^{2}$, the elfth wotacerpal, $\mathrm{I}$, radilus; $\mathrm{U}$, vina; $\mathrm{H}$, humorus; CL, elevielo; s, seapula; SP, spine of soapula.

FIg. 2. Volas aurface of the left foot of fenalo 75 days old. KR. S and $\mathrm{S}^{\mathrm{I}}$. sesanoid bones; P. poster $10 x$ walking pad; $C$, eartilage of flret cigit; it, metaoarpal of plrst diglt; FP, phalanx of flest digl; RA, radiele; uL, uinure: $\mathrm{R}$, radius; $\tilde{V}_{\text {, ulna. }}$

Fi8. 3. Loft foro 11 mb of a 55 day embryo (nale). XS. The atipled area indieates the portion that 18 ossified. C. capltate; H, hemate; $\mathrm{RA}$, racilale; $L_{3}$ Imare; U. ulnare; $\mathrm{EP}$. dlatal oplphysis of the radius; $\mathrm{BU}$, Alstel eplphysis of alna; CA? eapitulum: PE. proximal eplphasla of ulna; os: groater tuberosity of hemarus; $\Lambda P$, ecromion procoss. 
PLATIE I.

$$
\begin{gathered}
D=D, \ldots \\
M-D
\end{gathered}
$$
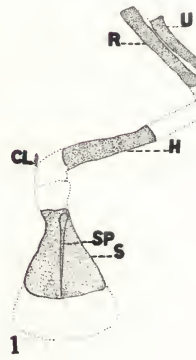

1
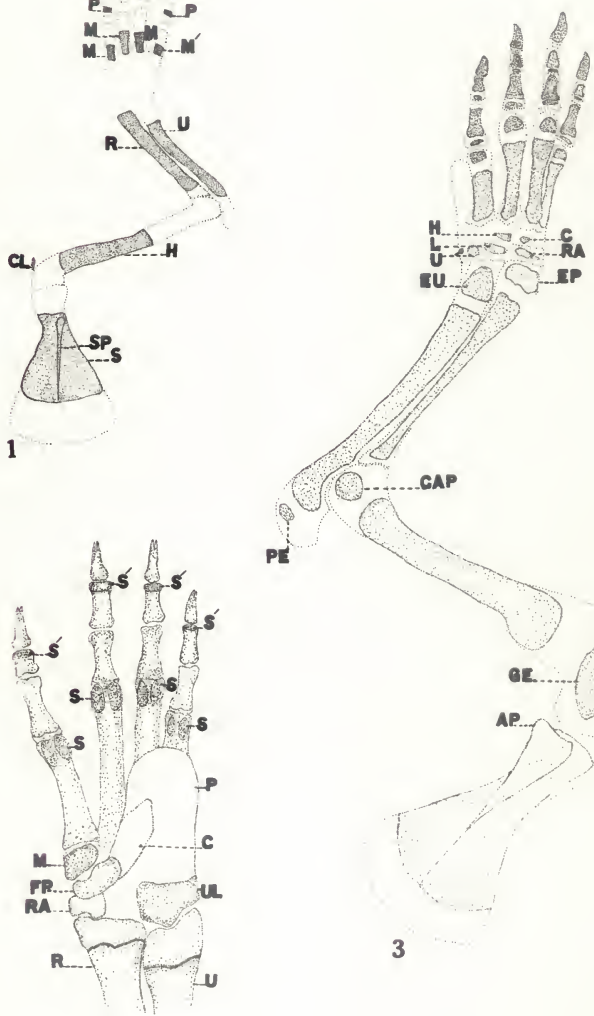

$\rightarrow$

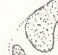

6
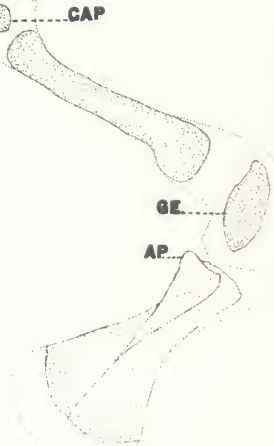


\section{PIATE II.}

F18. 4. Loft front log of a gulnoa-pig one day after birth. X3. The firet digit whieh normally wovid not be seen in the doreal view has been folded beok so that is is shows here. AD, second digit; DP, distal phalanx; SP, aecond Aiglt; PP, first phelenx; $F D$, Pirst digit; $C$, centrale; FP, trapeso1d; MI, Plrst metacarpal; T, trapezium; PH, phalanx of etrst digit; RA, radiale; UL, uinare; LV, Iunare;

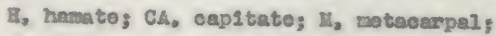
FI, elfth algit: FPD, fourth digit; FD, thisd diglt $\mathrm{R}$, redius; $\mathrm{V}$, wna; $\mathrm{CL}$, elavicle; $\mathrm{M}^{\mathrm{I}}$, humerus; $\triangle P$, aeromion process; S, scapula; $\nabla$, vertebral cart1lage of seapule. 
PLATE II.

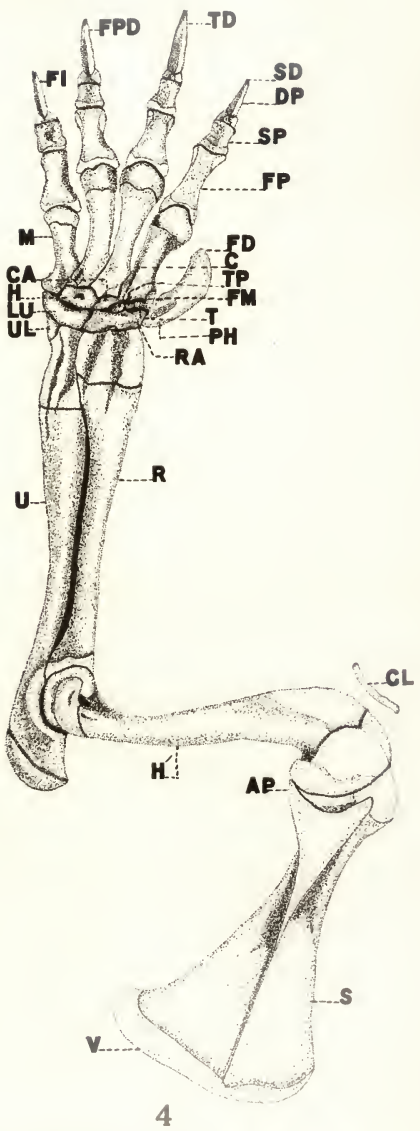


Dafe Due

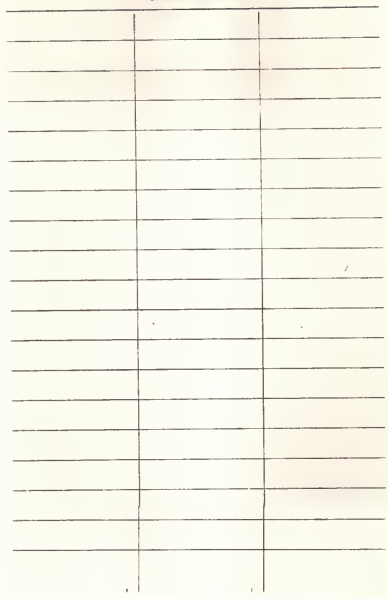

